\title{
Detection of Human Papillomavirus DNA in Genital Condylomata in Women and Their Male Partners by Using In Situ Hybridization with Digoxygenin Labeled Probes
}

\author{
Ryo Konno, Kazuo Shikano, Masayuki Horiguchi, \\ Atsushi Endo, Hidetoshi Chiba, Nobuo Yaegashi, \\ Shinji Sato, Hajime Yajima, Toru Tase and Akira \\ YAJIMA
}

Department of Obstetrics and Gynecology, Tohoku University, School of Medicine, Sendai 980

Konno, R., Shikano, K., Horiguchi, M., Endo, A., Chiba, H., Yaegashi, N., Sato, S., Yajima, H., TASe, T. and Yajima, A. Detection of Human Papillomavirus DNA in Genital Condylomata in Women and Their Male Partners by Using In Situ Hybridization with Digoxygenin Labeled Probes. Tohoku J. Exp. Med., 1990, 160 (4), 383-390 — Twelve couples (12 women and their male partners) presenting genital warts were investigated in order to evaluate the sexual transmission of human papillomavirus (HPV) in mutual partners and the localization of HPV DNA. Formalin-fixed, paraffin-embedded biopsy samples of 12 vulvar condylomata, and 12 penile condylomata from male partners were analyzed for the presence of HPV DNA-6, -11, and 16/18 by using in situ hybridization with digoxygenin labeled DNA probes. HPV DNA was identified in 9 women $(75 \%)$ and in 9 men $(75 \%)$. HPV- 6 was frequently identified, being revealed in $42 \%$ of the vulvar speciemens, in $67 \%$ of the cervical specimens and $58 \%$ of the penile specimens. Seven of $9(77 \%)$ positive couples shared the same HPV DNA, and 2 couples harbored different HPV DNA types between the partners. The signal intensity of the HPV DNA was generally strong in superficial cell layers, weak in parabasal or basal cell layers. No malignant lesions resulted from the condyloma acuminatum caused by HPV-6 or -11. There were only mild dysplasia in the both sexes. vulva, cervix and penis; condyloma; human papillomavirus (HPV) ; male partners ; in situ hybridization

Condyloma acuminatum is currently accepted to be a sexually transmitted disease (STD) caused by human papillomavirus (HPV) infection. HPV affects the anogenital tract in both sexes, and evidence has accumulated that HPV infections of the cervix, vulva and penis are associated with epithelial proliferation and malignant lesions (Gissmann et al. 1982 ; Reid et al. 1982 ; Durst et al. 1983 ; Okagaki 1984; Campion et al. 1985; Syrjänen 1986; Schneider et al.

Received January 22, 1990 ; revision accepted for publication March 27, 1990. 
1987 ; Barrasso et al. 1988; Zderic et al. 1989).

In our STD clinic, $58 \%$ of the male sexual partners of the women with the vulvar condylomata had penile condylomata. Penile condylomata occurred more frequently in the male partners of women with than without CIN (Tase et al. 1988). Campion et al. (1985) also reported that $76 \%$ of women with only one sexual partner who had penile condyloma had similar genital warts, and HPV DNA was detected in $77 \%$ of the women with both condylomata and CIN.

HPV infection was confirmed by detecting viral particles by electron microscopy (Della Torre et al. 1978; Laverty et al. 1978) and by identifying papillomavirus antigens (strucrural protein) by immunohistochemistrical techniques (peroxidase-antiperoxidase method) (Woodruff et al. 1980; Kurman et al. 1981).

Recently, the development of molecular biology methods has provided a means of detecting HPV DNA in the genital tract (Zachow et al. 1982; Okagaki et al. 1983). We also reported that Southern blot hybridization is more sensitive than immunohistochemistry or electron microscopy (Sato et al. 1987), and in situ hybridization is a particularly powerful technique for analyzing the localization of HPV DNA in paraffin-embedded tissues of cervical and vulvar lesions (Tase et al. 1988 ; Sato et al. 1989).

This was a study of women with genital warts and their male partners with regard to the relationship of the HPV type and the localization of HPV DNA using in situ hybridization with digoxygenin labeled DNA probes.

\section{Materials and Methods}

Formalin-fixed, paraffin-embedded biopsy samples from 12 couples presenting with genital warts (female vulvar and cervical condylomata and penile condylomata from male partners) from 1985 to 1988 in the STD clinic of the hospital of Tohoku University School of Medicene. These samples were confirmed by histological diagnosis, and then were subjected to this study using in situ DNA hybridization. Of 12 women with vulvar condylomata, 6 also had cervical flat condylomata. We performed this study accoring to the modified method of the previous reports (Ostrow et al. 1987; Tase et al. 1988). Molecularly-cloned HPV-6, -11, -16 and 18 DNA were excised with restriction enzyme from their plasmid vectors (pBR322). HPV DNA probes were prepared using a Nonradioactive DNA Labeling and Detection Kit (Boehriger Mannheim Biochemical, Mannheim, FRG). The DNA probes were labeled by random primed incorporation of digoxigenin-labeled deoxyuridine-triphosphate (dUTP). The dUTP was linked via a space-arm to the steroid hapten-digoxygenin. Labeled DNA probes were examined for specificity and sensitivity by dot blot hybridization before in situ hybridization. After hybridization to the target DNA, hybridization were detected by enzyme-linked immunoassay using an antibody-conjugate (antidigoxygenin alkaline phoshatase conjugate) and subsequent enzymecatalyzed color reaction with BCIP (5-bromo-4-chloro-3-iodolylphosphate) and NBT (Nitroblue tetrazolium).

Initially tissue samples were fixed in buffered $10 \%$ formalin and embedded in paraffin for routine histological examination. Paraffin blocks were cut into $5 \mu \mathrm{m}$ sections and mounted on Denhardt's treated and acetylated microscopic slides. Following deparaffinization with xylene and ethanol dehydration, sections were treated subsequently with $0.2 \mathrm{~N} \mathrm{HCl}(30 \mathrm{~min})$, triethanolamine hydrochloride solution $(0.153 \mathrm{M}, \mathrm{pH} 7.4,15 \mathrm{~min})$, 
$3 \times \operatorname{SSC}\left(30 \mathrm{~min}, 68^{\circ} \mathrm{C}\right)$, digitonin $(0.05 \%, \mathrm{pH} 7.4,5 \mathrm{~min})$, distilled water, proteinase $\mathrm{K}(10$ $\left.\mu \mathrm{g} / \mathrm{ml}, 15 \mathrm{~min}, 37^{\circ} \mathrm{C}\right)$, ethanol dehydration and RNase A $(100 \mu \mathrm{g} / \mathrm{ml})$ and RNase T1 (10 $\mu$ units $\left./ \mathrm{ml}, 60 \mathrm{~min}, 37^{\circ} \mathrm{C}\right)$. After refixation with $5 \%$ paraformaldehyde $(2 \mathrm{hr})$, the sections were washed in $2 \times \mathrm{SSC}$, dipped in water and dehydrated with graded ethanol.

The sections were hybridized using HPV-6, 11 and 16/18 probes. Hybridization solution contained $50 \%$ formamide, $10 \%$ dextran sulfate, $0.06 \mathrm{ng} / \mu \mathrm{l}$ of digoxygenin-dUTP labeled HPV DNA probes. The hybridization solution was pipetted onto the sections, which were denatured, then quenched on ice. The slides were hybridized overnight $\left(37^{\circ} \mathrm{C}\right)$. The sections were subsequently washed under stringent conditions, twice in $6 \times \mathrm{SSC}, 45 \%$ formamide ( $15 \mathrm{~min}, 37^{\circ} \mathrm{C}$ ), twice in $2 \times \operatorname{SSC}(5 \mathrm{~min}$, room temperature) and twice in $0.2 \times$ SSC $\left(15 \mathrm{~min}, 45^{\circ} \mathrm{C}\right)$. The slides were immersed in $1 \%$ blocking reagent (quality checked skim milk, $30 \mathrm{~min}$ ), and washed in Tris- $\mathrm{HCl}$ saline buffer. The anti-digoxygenin conjugated to alkaline phosphatase $(1: 5000)$ was spotted on the sections, then unbound anticonjugate was removed with Tris- $\mathrm{HCl}$ saline. After the color solution containing NBT and BCIP was added on the slides, the slides were placed in a moistured plastic boxes for $6 \mathrm{hr}$. Then the slides were washed with Tris- $\mathrm{HCl}$ to stop the color reaction. The slides were examined by light microscopy for the presence of purplish blue color grains of HPV DNA over the nuclei. However, post-hybridization wash was performed under stringent conditions, the cross hybybridization due to homology of sequences between HPV-6 and 11 could not be avoided completely. We identified HPV DNA types by judgment of signal intensity over the nuclei. Negative controles were obtained using pBR 322 probes and endometrial tissues known to be HPV DNA negative.

Chemicals used were as follows: Nonradioactive DNA Labeling and Detection Kit (Boehringer Mannheim Biochemical), triethanolamine hydrochloride (Sigma, St. Louis, MO, USA), digitonin (Sigma), proteinase K (Boehiringer Mannheim Biochemical), RNase A (Sigma), and RNase T1 (Worthington Biochemical, Freehold, NJ, USA).

\section{RESULTS}

We examined specimens for 12 couples (12 women and their 12 male partners). HPV DNA was detected in $9(75 \%)$ women and in $9(75 \%)$ male partners. HPV-6 was identified in 5 of $12(42 \%)$ vulvar condylomata, in 4 of $6(67 \%)$ cervical condylomata and in 7 of $12(58 \%)$ penile condylomata, and HPV-11 was identified in 2 of $12(17 \%)$ vulvar and 2 of $12(17 \%)$ penile condylomata. HPV-16/18 was identified in 1 of $12(8 \%)$ vulvar condylomata and 1 of $6(17 \%)$ cervical condylomata. Seven of $9(78 \%) \mathrm{HPV}$-positive couples shared the same HPV DNA type. Two couples showed different HPV types between partners

TABLE 1. Result of in situ hybridization of female vulvar, cervical condyloma and penile condyloma of their male partners

\begin{tabular}{lccc}
\hline & \multicolumn{2}{c}{ Female } & Male \\
\cline { 2 - 4 } & Vulva & Cervix & Penis \\
\hline HPV positive & $8 / 12(67 \%)$ & $5 / 6(83 \%)$ & \\
& $9 / 12$ & $(75.0 \%)$ & $9 / 12(75 \%)$ \\
HPV-6 positive & $5 / 12(42 \%)$ & $4 / 6(67 \%)$ & $7 / 12(58 \%)$ \\
HPV-11 positive & $2 / 12(17 \%)$ & $0 / 6(0 \%)$ & $2 / 12(17 \%)$ \\
HPV-16/18 positive & $1 / 12(8 \%)$ & $1 / 6(17 \%)$ & $0 / 12(0 \%)$ \\
\hline
\end{tabular}


TABLE 2. Result of in situ hybridization of condyloma in twelve couples

\begin{tabular}{ccccc}
\hline & \multicolumn{3}{c}{ Female } & Male penis \\
\cline { 2 - 3 } Couple No. & Vulva & Cervix & 6 \\
\cline { 2 - 3 } 2 & 11 & $16 / 18$ & 6 \\
3 & 6 & 6 & 6 \\
4 & - & 6 & 6 \\
5 & 6 & 6 & 6 \\
6 & 6 & $\mathrm{~N}$ & 6 \\
7 & 6 & 6 & - \\
8 & - & $\mathrm{N}$ & 11 \\
9 & $16 / 18$ & $\mathrm{~N}$ & 6 \\
10 & 6 & $\mathrm{~N}$ & - \\
11 & - & $\mathrm{N}$ & - \\
12 & - & - & 11 \\
\hline
\end{tabular}

6, HPV-6; 11, HPV-11; 16/18, HPV-16 or $18 ;-, \mathrm{HPV}$ negative; N, no sample.

TABLE 3. Correlation between HPV types detected from sexual partners

\begin{tabular}{cccc}
\hline & \multicolumn{3}{c}{ HPV type in females } \\
\cline { 2 - 4 } & 6 & 11 & $16 / 18$ \\
\hline HPV type in males & & & \\
6 & 6 & $1^{\mathrm{a}}$ & $1^{\mathrm{a}}$ \\
11 & 0 & 1 & 1 \\
$16 / 18$ & 0 & 0 & 0 \\
\hline
\end{tabular}

a HPV-11 was detected in vulva and HPV-16/18 was detected in cervix in the same female.

(Tables 1,2 and 3). The purplish blue grains of HPV-positive signals were localized strongly in sugerficial cell layers, moderately in intermediate cell layers and weakly in parabasal and basal cell layers (Fig. 1). Most grains of HPV DNA were present in the koilocytotic cells, but also in other areas, in which the cells necessarily presented koilocytotic. By dot blot hybridization using digoxygenin labeled probes, 1 pg of HPV-6, 11, 16 and 18 DNA was detected under stringent condition $(5 \times \mathrm{SSC}$ twice, $2 \times \mathrm{SSC}$ twice and $0.1 \times \mathrm{SSC}$ twice).

The subjects were also examined for cytodiagnosis and histodiagnosis (Table 4). Three of $12(25 \%)$ females were in class IIIA on cytodiagnosis of the cervix, while none of the male subjects showed any dysplastic change on urinary cytodiagnosis. Histodiagnosis revealed mild dysplasia in 3 of $12(25 \%)$ cervical specimens, 2 of $12(17 \%)$ vulvar spcimens and 2 of $12(17 \%)$ penile specimes. 

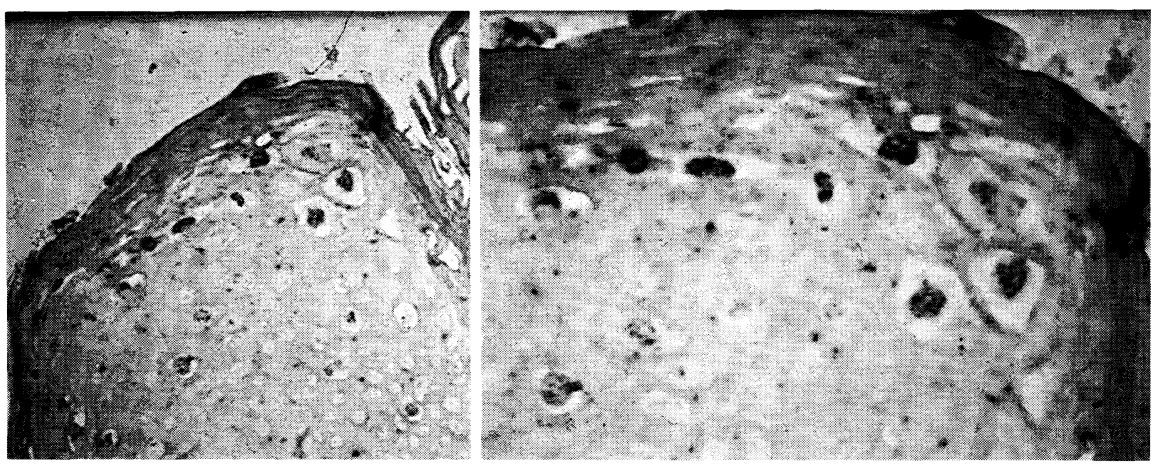

Fig. 1. Presence of HPV-6 DNA in condyloma by in situ hybridization. Original magnification, left $\times 200$, right $\times 400$.

TABLE 4. Cytodiagnosis of cervix and histodiagnosis of cervix, vulva and penis

\begin{tabular}{rrlll}
\hline \multirow{2}{*}{$\begin{array}{c}\text { Couple } \\
\text { No. }\end{array}$} & \multicolumn{2}{c}{ Female } & \multicolumn{1}{c}{ Male } \\
\cline { 2 - 5 } & Cytology & \multicolumn{1}{c}{ Cervix } & \multicolumn{1}{c}{ Vulva } & \multicolumn{1}{c}{ Penis } \\
\hline 1 & II & & Condyloma & Condyloma \\
2 & IIIA & Condyloma & Condyloma & Condyloma +mild dys. \\
3 & IIIA & Mild dys. & Condyloma & Condyloma \\
4 & IIIA & Mild dys. & Condyloma & Condyloma \\
5 & II & & Condyloma+mild dys. & Condyloma \\
6 & II & No change & Condyloma+mild dys. & Condyloma \\
7 & II & Cervicitis & Condyloma & Condyloma + mild dys. \\
8 & II & Condyloma + mild dys. & Condyloma & Condyloma \\
9 & II & Condyloma & Condyloma & Condyloma \\
10 & II & sq. metaplasia & Condyloma & Condyloma \\
11 & II & Condyloma & Condyloma & Condyloma \\
12 & II & & Condyloma & Condyloma \\
\hline
\end{tabular}

Mild dys., mild dysplasia; sq. metaplasia, squamous metaplasia.

Any cases had not progressed to malignant lesions during follow-up for 2 to 5 years.

\section{Discussion}

With conventional colorimetric in situ hybridization using biotinilated probes, HPV DNA below 50-100 copies per cell could not be detected. Recently, however, Heiles et al. (1988) reported that HPV DNA was detected with high sensitivity in SiHa cells (HPV-16 DNA 2-3 per cell) and HeLa cells (HPV-18 DNA 40-200 per cell) using in situ hybridization with digoxygenin labeled DNA probes. DNA detection assay using digoxygenin could be carried out in a routine 
laboratory. Additionally, the entire course of detection with in situ hybridization using digoxygenin labeled probes instead of tritium labeled probes could be reduced to 3 days, while it took about 1 month for results to be obtained by autoradiography using tritium (Tase et al. 1988). Since non-specific color devolopment in the interstitial areas other than the squamous epithelium could not be blocked completely in spite of post-hybridization wash under stringent condition, it is necessary to study further reaction time, blocking reagent which was a $1 \%$ skim milk and so on in order to suppress the background.

The incidence of condyloma has tended to increase among patients, in particular young patients, with STD in recent years (Okagaki 1984). In the STD clinic of our department, female patients diagnosed clinically as having condyloma are subjected to examination of the vulva, vagina and cervix, and to biopsy for histodiagnosis, followed by treatment using $\mathrm{CO}_{2}$ Laser. On another day, their sexual partners are also called to examin and treat together (Tase et al. 1986).

Kurman et al. (1981) detected papillomavirus antigens in $50 \%$ of condyloma and dysplastic lesions by using immunohistochemistry with bovine papillomavirus antigen. The present method, which detected HPV DNA in $75 \%$ of the condyloma tissues, allowed more frequent detection of HPV infection than using an immunohistochemical method. HPV DNA was detected in 9 of $12(75 \%)$ couples and 7 of $9(78 \%)$ positive couples shared the same type of HPV. The results confirmed that $\mathrm{HPV}$ infection was sexually transmitted in most cases. Inconsistent of HPV types in either vulva, cervix or penis of two couples indicated the occurrence of mixed infections.

Yoshikawa et al. (1985) examined condylomata in 60 Japanese women by Southern blot hybridization, and detected HPV DNA in $92 \%$ of them (HPV-6a in $55 \%$, HPV-6c in $24 \%$ and HPV-11c in 21\%). Sakuma et al. (1988) detected HPV DNA in $91 \%$ of 35 anogenital condylomata in Japanese men (HPV-6a in $40 \%$, HPV-6c in 6\%, HPV-11a in $37 \%$ and HPV-16/18 in $0 \%$ ). The distribution of detected HPV types in their investigations was similar to our result. There ware $25 \% \mathrm{HPV}$-undetectable condylomata in this study, the reasons were thought to be lower sensitivity of in situ hybridization than Southern blot hybridization and occurrence of condyloma caused by other unknown HPV types.

Although some investigators (Syrjänen 1986; Schneider et al. 1987) reported that the condylomatous lesions with HPV-16 or 18 occasionally become malignant, common condyloma caused by HPV-6 or 11 seemed seldem not to be malignant.

According to Barrasso et al. (1988) who investigated HPV infection in 50 married couples with only one partner, the HPV DNA type was consistent in $32 \%$ and inconsistent in $32 \%$, and in the remaining $36 \%$, one of the partners was negative for HPV. Most of the tissues in which HPV-6 or 11 was detected showed condyloma with only slight histological changes as well as mild dysplasia. In the couples in whom HPV-16, 18, 31, 33 or 35 was detected, HPV infections were 
related to intraepithelial neoplasia. Our results also suggest that there is no relationship between malignant transformation and condyloma caused by HPV-6 or 11. No cases of condylomata in the study have become carcinoma, but careful follow-up is necessary for the cases of HPV-16/18 positive.

\section{References}

1) Barrasso, R., Huynh, B., DeBrux, J., Croissant, O. \& Orth, G. (1988) Genital papillomavirus infections in regular sexual partners. Abstracts of papers presented at the Seventh International Papillomavirus Workshop in Côte d'Azur, 236.

2) Campion, M.J., Singer, A. \& Clarkson, P.K. (1985) Increased risk of cervical neoplasia in consrts of men with penile condylomata acuminatum. Lancet, 1, 943-946.

3) Della Torre, G., Pilloti, S., DePalo, G. \& Rieke, F. (1978) Viral particles in cervical condylomatous lesions. Tumori, 64, 549-553.

4) Durst, M., Gissman, L., Ikenborg, H. \& zur Hausen, H. (1983) A papillomavirus DNA from a cervical carcinoma and its prevalence in cancer biopsy samples from different geographic regions. Proc. Natl. Acad. Sci. USA, 80, 3812-3815.

5) Gissmann, L., DeVillers, E.M. \& zur Hausen, H. (1982) Analysis of human genital warts (condylomata acuminatum) and other genital tumors for human papillomavirus type 6 DNA. Int. J. Cancer, 29, 143-146.

6) Heiles, H.B.J., Genersch, E., Kessler, C., Neumann, R. \& Eggers, H.J. (1988) In situ hybridization with digoxygenin-labeled DNA of human papillomaviruses (HPV-16/ 18) in HeLa and SiHa cells. BioTechniques, 6, 978-981.

7) Kurman, R.J., Shah, K.H., Lancaster, W.D. \& Jenson, B. (1981) Immunoperoxidase localization of papillomavirus antigens in cervical dysplasia and vulvar condylomas. Am. J. Obstet. Gynecol., 140, 981-935.

8) Laverty, C.M., Russel, P., Hills, E. \& Booth, N. (1978) The significance of condylomatous warts virus infection of the cervical transformation zone. Acta Cytol., 22, 195-201.

9) Okagaki, T. (1984) Female genital tumors associated with human papillomavirus infection, and the concept of genital neoplasm-papilloma syndrome (GENPS). Pathol. Annu., 19, 31-62.

10) Okagaki, T., Twiggs, L.B., Zachow, K.R., Clark, B.A., Ostrow, R.S. \& Faras, A.J. (1983) Identification of human papillomavirus DNA in cervical and vaginal intraepithelial neoplasia with molecular cloned virus-specific DNA probes. Int. J. Gynecol. Pathol., 2, 153-159.

11) Ostrow, R.S., Manias, D.A., Clark, B.A., Okagaki, T., Twiggs, L.B. \& Faras, A.J. (1987) Detections of human papillomavirus DNA in invasive carcinoma of the cervix by in situ hybridization. Cancer Res., 47, 649-653.

12) Reid, R., Stanhope, C.R. \& Hershman, B.R. (1982) Genital warts and cervical cancer. I. Evidence of a association between subclinical papillomavirus infection and cervical malignancy. Cancer, 50, 377-387.

13) Sakuma, S., Minagawa, H., Mori, R., Kumazawa, J., Sagiyama, K. \& Yanagi, K. (1988) Human papillomavirus DNA in condylomata acuminata from Japanese males. Diagn. Microbiol. Infect. Dis., 10, 23-29.

14) Sato, S., Okagaki, T., Clark, B.A., Twiggs, L.B., Fukushima, M., Ostrow, R.S. \& Faras, A.J. (1987) Sensitivity of koilocytosis, immunocytochemistry, and electron microscopy as compared to DNA hybridization in detecting human papillomavirus in cervical and vaginal condyloma and intraepithelial neoplasia. Int. J. Gynecol. Pathol., 5, 297-307.

15) Sato, S., Tase, T., Yajima, H., Shikano, K., Konno, R., Yajima, A., Fukushima, M. \& Okagaki, T. (1989) Human papillomavirus DNA in vulver lesions. Jpn. J. Cancer 
Chomother., 16, PART-2, 1708-1713.

16) Schneider, A., Sawada, E., Gissman, L. \& Shah, K. (1987) Human papilloma virus in women with a history of abnormal Papanicolou smears and in their male partners. Obstet. Gynecol., 64, 554-562.

17) Syrjänen, K.J. (1986) Human papillomavirus (HPV) infections of the female genital tract and their associations with intraepithelial neoplasia and squamous cell carcinoma. Pathol. Annu., 21, 53-89.

18) Tase, T., Oikawa, N., Toki, T., Wada, Y. \& Yajima, A. (1986) Relationship of vulvar condyloma to cervical intraepithelial neoplasia and a study of male sexual partners. J. Jpn. Soc. Clin. Cytol., 25, 683-689.

19) Tase, T., Okagaki, T., Clark, B.A., Manias, D.A., Ostrow, R.S., Twiggs, L.B. \& Faras, A.J. (1988) Human papillomavirus types and localization in adenocarcinoma and adenosquamous carcinoma of the uterine cervix: A study by in situ DNA hybridization. Cancer Res., 48, 993-998.

20) Woodruff, J.O., Braun, L., Cavalieri, R., Gupta, P., Pass, F. \& Shah, K.B. (1980) Immunologic identification of papillomavirus antigen condyloma tissues from the female genital tract. Obstet. Gynecol., 56, 727-732.

21) Yoshikawa, H., Matsukura, T., Yoshiike, T., Yamaoto, E., Kawana, T. \& Mizuno, M. (1985) Human papillomavirus DNA in female condylomata. Acta Obstet. Gynecol. Jpn., 37, 1225-1230.

22) Zachow, K., Ostrow, R.S., Bendow, M., Watts, S., Okagaki, T., Pass, F. \& Faras, A. (1982) Detection of human papillomavirus DNA anogential neoplasias. Nature, 300, 771-773.

23) Zderic, S.A., Carpiniello, V.L., Malloy, T.R. \& Rando, R.F. (1989) Urological application of human papillomavirus typing using deoxyribonucleic acid probes for the diagnosis and treatment of genital condyloma. J. Urol., 141, 63-65. 